AGRO EKONOMI, Vol 32, Issue 1, June 2021, Page.12-25

DOI : http://doi.org/10.22146/ae.60713

ISSN 0215-8787 (print), ISSN 2541-1616 (online)

Available at https://jurnal.ugm.ac.id/jae/

\title{
Characteristics and Preferences of Chicken Meat Consumers Before and During Covid-19 Pandemic in Sleman Regency
}

\author{
Swastanita Sri Setyanovina ${ }^{1}$, Any Suryantini ${ }^{2}$, Masyhuri ${ }^{3}$ \\ ${ }^{1}$ Postgraduate Program of Agribusiness Management, Faculty of Agriculture, \\ Universitas Gadjah Mada, \\ ${ }^{2,3}$ Department of Agricultural Sosio-Economics, Faculty of Agriculture, \\ Universitas Gadjah Mada \\ Jalan Flora, Bulaksumur, Depok, Sleman, Daerah Istimewa Yogyakarta ${ }^{1,2,3}$ \\ swastanita@mail.ugm.ac.id
}

Submitted : 19 October 2019 ; Revised : 22 March 2020 ; Accepted : 29 April 2021

\begin{abstract}
People purchase and consume poultry meat to fulfill their animal protein needs. In early 2020, COVID-19 spread globally as well as in Indonesia, changing the social and economic conditions, which further affect people's behavior in purchasing chicken meat. There were two types of this meat-broiler and free-range chicken-with different characteristics (attributes) that affect consumer preference. Consumers can choose chicken meat according to their needs and desires by considering its attributes. This study aims to determine chicken meat consumers' characteristics before and during the COVID-19 pandemic and the differences in consumer preferences for broilers and free-range chickens. The research was conducted in Sleman Regency from April to May 2020. The primary data was collected through an electronic form from 100 respondents chosen by random sampling. The descriptive analysis was employed to investigate chicken meat characteristics, and the Fishbein Multi-attribute was used to understand the consumer preference for chicken meat. The results showed that consumers continued to buy chicken meat during the COVID-19 pandemic but changed the amount of purchase and the purchase location. Two main attributes affecting consumer preferences, both for broilers and free-range chickens were the aroma and freshness. The third attribute affecting consumer preference for broilers (free-range chicken) was the meat color (halal status).
\end{abstract}

Keywords: Chicken meat, Consumer preference, Fishbein multi-attributes

How to cite : Setyanovina, S.S., Suryantini, A., and Masyhuri. 2021. Characteristics and Preferences of Chicken Meat Consumers Before and During Covid-19 Pandemic in Sleman Regency. Agro Ekonomi 32(1), 12-25

\section{INTRODUCTION}

Chicken meat is one source of animal protein that is widely consumed by the public. In the beginning, the Indonesian people were accustomed to consuming free-range chicken meat until the broilers appeared in 1980, which were initially difficult to accept by the community. Until the end of 1980, the broiler consumers increased. Broiler chicken then becomes the competitor for free-range chicken. Broiler and 
free-range chicken have different characteristics. Local chickens have nutritional qualities, tastes, and textures making them more unique than broilers (Choe et al., 2010).

The increasing broiler producers was followed by the increase in broiler demand. Broiler and free-range chicken production increased, but broiler chicken meat production could reach five times more than the free-range chicken meat (Badan Pusat Statistik, 2019). Although free-range chicken meat is less than broiler chicken meat, free-range chicken meat still has its place in people's hearts. Besides, free-range chicken is not dependent on Day Old Chick (DOC) companies from foreign companies. It shows that the market for free-range chicken meat can still grow, and the potential for free-range chicken business for local farmers is increasingly opened. The result of previous study shows that local chicken had a potential market in urban and rural areas because consumer preference for local chicken meat's added value was very high. Consumer perception of local chicken meat had a positive influence on consumer preference for local chicken meat (Mufeeth \& Thariq, 2019).

People's choice to buy broilers and free-range chicken naturally varies concerning in consumer preferences. Consumer preferences can occur if a person deals with two or more choices of products or services to be consumed, and consumers can choose between all the choices to meet their needs. The different taste and texture of chicken meat from beef, mutton, and pork contribute to consumer preference on chicken meat. Consumers are aware of the positive and negative effects of chicken meat consumption. The amount of consumption, storage of chicken meat, cleaning of chicken meat, and cooking time of chicken meat must be done properly to prevent health problems (Jayaraman et al., 2013).

The different consumer preferences for chicken meat have a major influence on purchasing decisions, especially with regards to broiler chicken meat. Consumer preference for this meat is related to chicken meat attributes. Consumers can choose a product having attributes according to their needs and desires (Pouta et al., 2010).

At the end of 2019, the COVID-19 pandemic began in Wuhan, China, and then spread throughout the world, including Indonesia, COVID-19 impact occurred in March 2020 accompanied by various policies to prevent disease transmission. It had an impact on people's lives, such as decreasing income. On the other hand, people still had to meet their food needs, including the need for protein, one chicken meat source. Changes in 
conditions occured in the community due to the COVID-19 pandemic could also affect people's behavior in buying chicken meat to fulfill their food needs.

Research related to consumer preferences conducted in Indonesia focuses on broiler chicken meat. It is challenging to find research related to consumer preference for free-range chicken meat. This research has a novelty from the previous research that compares consumer preferences for broilers and free-range chicken, also the condition during the COVID-19 pandemic. The attributes of broiler chicken meat used in previous studies were package, texture, and freshness (Abdul Hadi et al., 2013); price, taste, form of the meat, proximity, and availability (Kwadzo et al., 2013); part of the carcass, carcass color, meat aroma, the freshness of meat, skin cleanliness, bone condition, and carcass weight (Pratama et al., 2015); traceability, price, brand, animal breed, color, animal welfare, country of origin, organic label, nutritional information, tenderness, quality certifications, and taste (Merlino et al., 2017); meat color, skin cleanliness, meat weight, the physical character of the meat, meat freshness, and meat slice (Mayulu et al., 2019). In this study, the attributes of chicken meat used are formalin-free, bacteria-free, diseasefree, halal, taste, nutrient content, meat freshness, meat aroma, meat color, fat content, skin cleanliness, price, and benefits provided.

Therefore, the aims of this study are 1) to find out the characteristics of chicken meat consumers before and during the COVID-19 pandemic in Sleman Regency and 2) to determine the differences in consumer preferences for the attributes of broilers and freerange chickens in Sleman Regency. This research is intriguing and important because it provides information to chicken meat traders related to consumer preferences which have never been done before.

\section{METHODS}

The research location was determined intentionally (purposive sampling) by researchers, namely in the Regency of Sleman, considering the highest population and chicken meat production in Yogyakarta Special Region Province (Dinas Pertanian Yogyakarta, 2020). The sampling technique used was probability sampling, giving each member of the population elected as a sample member and randomly chose from the population. Respondents were the end consumers over or equal to 18 years old since they can make their own decision, purchased broiler and/or freerange chicken meat within the last one month, also understand the technology 
and have email so they can fill out online questionnaires via a google form. Data was collected online through google form from April to May 2020, with 100 respondents.

\section{Validity and Reliability Test}

The validity test shows the level or degree of accuracy of the research in measuring the variables that are actually measured. The program used to test the validity was SPSS with the Pearson Product Moment test. The decisionmaking criteria for the validity test are as follows (Purwoto, 2007):

Ho : item tested is invalid

Ha : item tested is valid

1. If $r$ value $\geq r$ table, then Ho is rejected, so the item tested is valid.

2. If $r$ value $<r$ table, then Ho is not rejected, so the item tested is invalid.

The reliability test was used to determine the consistency of a measurement's instrument. It means that when the measurement is repeated, the instrument supposes to remain consistent. The reliability test is the level or degree of consistency of a measuring instrument to measure the measured target. The SPSS program processed the reliability test. The criteria for the reliability test are as follows (Purwoto, 2007): a. If Cronbach's Alpha value $\geq 0.60$, then the items tested is reliable.

b. If Cronbach's Alpha value $<0.60$, then the items are not reliable.

\section{Fishbein Multi-Attributes Model}

Fishbein's multi-attribute model is consumers' attitude to objects by comparing two or more products based on the product's attributes. This model shows that a product has attributes with different levels of importance according to consumer perception. The Fishbein multi-attributes model is summarized in the following formula (Prasetijo \& Ihalauw, 2005):

$\mathrm{Ao}=\sum_{i=1}^{n} b i . e i$

in which:

Ao : consumer attitude score for object 0

bi : the level of consumer belief that the object has the i-th attribute

ei : the importance of weight given to i-th attribute by consumer

$n$ : the number of attributes on an object

The interval scale was used to determine whether the consumer attitude was good or not regarding the product. The interval scale formula used is as follows: 
Interval scale: $\frac{m-n}{b}$

in which:

m : the highest possible score

n $\quad$ : the lowest possible score

b : the number of research scale

$\mathrm{m} \quad=5 \times 5 \times 14=350$

$\mathrm{n} \quad=1 \times 1 \times 14=14$

Interval scale $=\frac{350-14}{5}$

$=67.2$

RESULTS AND DISCUSSION

Characteristics of Chicken Meat Consumers in Sleman

Purchasing activities will occur if consumers have income that can be spent on buying chicken meat. The COVID-19 pandemic that has occurred in Indonesia since March impacted on people's monthly income. Respondent income was grouped into seven groups, with the lowest group being income less than or equal to Rp. 500,000 and the highest group with an income of more than Rp. 10,000,000. The interpretation of income change was divided by broiler consumers and free-range chicken meat consumers.

During the COVID-19 pandemic, there was a change in income experienced by respondents, due to the government's policy, namely Large-Scale Social Restrictions (PSBB), to reduce the rate of spread, which impacted workplaces, such as many companies that were forced to lay off their employees or reduce the employee's salaries to continue operating. Twenty-nine percent of consumers experienced a decrease in income, and the remaining $71 \%$ did not experience a change in income.

The majority of respondents had jobs as civil servants, teachers, and private employees. Other jobs were freelance, day laborer, online motorcycle driver, and lecturer. The types of jobs most affected by the decline in income during the COVID-19 pandemic were private employees, teachers, entrepreneurs, and housewives. The private employees with fixed and declining incomes were almost equal due to the policies of their companies during the COVID-19 pandemic, some companies reduce the number of employees' salaries because their income was also decreasing. Teachers' jobs experienced income decrease because the education sector was hampered during the COVID-19 pandemic so that students did not attend the school and there was a decrease in tuition fees influencing teacher income to decrease as well. Civil servants experienced the least decline in income because the government sector was quite stable, there were $5.71 \%$ of civil servants who experienced a decrease in income following their institutional policies (Table 1). 
Table 1. Respondent Job Types

\begin{tabular}{lcccc}
\hline \multirow{2}{*}{ Job Types } & \multirow{2}{*}{ Percentage (\%) } & \multicolumn{3}{c}{ Income Change during COVID-19 Pandemic (\%) } \\
\cline { 3 - 5 } & & Fixed & Decreased & Total \\
\hline Civil servant & 35.00 & 94.29 & 5.71 & 100.00 \\
Teacher & 21.00 & 61.90 & 38.10 & 100.00 \\
Private employee & 19.00 & 52.63 & 47.37 & 100.00 \\
Entrepreneur & 5.00 & 40.00 & 60.00 & 100.00 \\
Housewife & 10.00 & 50.00 & 50.00 & 100.00 \\
Other & 10.00 & 80.00 & 20.00 & 100.00 \\
\hline
\end{tabular}

Source: Primary Data Analysis (2020)

Respondent income was mostly in the Rp. 3,100,000 - 5,000,000 group. Broiler chicken consumers were in all income categories. Only the Rp. 7,100,000 - 10,000,000 income category had not changed during the COVID-19 Pandemic. Consumers with the income category of less than Rp. 500,000 buy broiler chicken and no one bought freerange chicken because their income was adjusted to the price of broiler chicken, which was more affordable than freerange chicken. For free-range chicken consumers, there were two categories of income that had not changed during the COVID-19 pandemic. The income category remained unchanged was Rp. 5,100,000 - Rp. 7,000,000 and more than Rp. 10,000,000 because the consumers of free-range chicken meat in that category had jobs as civil servants and lecturers who did not experience a decrease in income. (Table 2).

This study wants to see the quantity meat purchases before and during the
COVID-19 pandemic. Total purchases of chicken meat were categorized into $0.5-1.5 \mathrm{~kg}$, more than $1.5 \mathrm{~kg}$ to $2.5 \mathrm{~kg}$, and more than $2.5 \mathrm{~kg}$. Meanwhile, groups of family members are divided into 1-2 people, 3-4 people, and more or equal to 5 people. The majority of chicken meat consumed in all family members is $0.5-1.5 \mathrm{~kg}$.

Families with 1-2 members were in five income categories. There were $17 \%$ of consumers with decreased income in these five income categories and 35\% with fixed income (Table 1 and Table 2). This decrease in income could lead to a decrease in the number of purchases of chicken meat. It was shown

by before the COVID-19 pandemic, families with 1-2 members bought 0.5$1.5 \mathrm{~kg}$ of chicken meat (63.64\%) and more than $1.5 \mathrm{~kg}$ (36.36\%), then during the COVID-19 pandemic, the number of respondents that bought $0.5-1.5 \mathrm{~kg}$ chicken meat increased, but 1.6 - $2.5 \mathrm{~kg}$ chicken purchased meat decreased. 
Table 2. Respondent Income Before and During the COVID-19 Pandemic in Sleman

\begin{tabular}{|c|c|c|c|c|c|}
\hline \multirow{3}{*}{$\begin{array}{c}\text { Income }(\mathrm{x} \\
\text { IDR } \\
1,000,000)\end{array}$} & \multicolumn{5}{|c|}{ Income Change during COVID-19 Pandemic (\%) } \\
\hline & \multicolumn{2}{|c|}{ Broilers Consumer } & \multicolumn{2}{|c|}{$\begin{array}{c}\text { Free-range Chicken } \\
\text { Consumer }\end{array}$} & \multirow[t]{2}{*}{ Total } \\
\hline & Fixed & Decreased & Fixed & Decreased & \\
\hline$\leq 0.50$ & 5.00 & 4.00 & 0.00 & 0.00 & 9.00 \\
\hline $0.51-1.50$ & 5.00 & 3.00 & 2.00 & 1.00 & 11.00 \\
\hline $1.60-3.00$ & 7.00 & 6.00 & 8.00 & 3.00 & 24.00 \\
\hline $3.10-5.00$ & 17.00 & 3.00 & 10.00 & 4.00 & 34.00 \\
\hline $5.10-7.00$ & 4.00 & 1.00 & 2.00 & 0.00 & 7.00 \\
\hline $7.10-10.00$ & 3.00 & 0.00 & 4.00 & 3.00 & 10.00 \\
\hline$>10.00$ & 1.00 & 1.00 & 3.00 & 0.00 & 5.00 \\
\hline Total (\%) & 42.00 & 18.00 & 29.00 & 11.00 & 100.00 \\
\hline
\end{tabular}

Source: Primary Data Analysis (2020)

Families with 3-4 members and more or equal to 5 members were in all income categories. Not all of the income categories experienced a decrease in income (Table 2 and Table 3). During the COVID-19 pandemic, the number of chicken meat purchases at $0.5-1.5 \mathrm{~kg}$ decreased, and 1.6 - $2.5 \mathrm{~kg}$ increased. It showed that most consumers increased the number of chicken meat purchases, which could be caused by many family members who were often at home during the COVID-19 pandemic.

Chicken meat was sold in various places such as traditional markets, modern markets, vegetable stalls, chicken slaughterhouses, mobile vegetable traders, and chicken stalls.

The COVID-19 pandemic occurred in Indonesia changed the place where consumers choose to buy chicken meat. As many as $98 \%$ of respondents stated that they had no difficulty buying chicken
Table 3. Cross Tabulation of Income and Number of Family Member during COVID-19 Pandemic

\begin{tabular}{lccc}
\hline $\begin{array}{c}\text { Income } \\
\text { IDR }\end{array}$ & $\begin{array}{c}\text { Number of Family Member } \\
\text { (people) }\end{array}$ \\
\cline { 2 - 4 } $1,000,000)$ & $1-2$ & $3-4$ & $\geq 5$ \\
\hline$\leq 0.50$ & $1 \%$ & $9 \%$ & $2 \%$ \\
$0.51-1.50$ & $2 \%$ & $10 \%$ & $2 \%$ \\
$1.60-3.00$ & $5 \%$ & $13 \%$ & $7 \%$ \\
$3.10-5.00$ & $2 \%$ & $19 \%$ & $8 \%$ \\
$5.10-7.00$ & $0 \%$ & $5 \%$ & $3 \%$ \\
$7.10-10.00$ & $0 \%$ & $6 \%$ & $1 \%$ \\
$>10.00$ & $1 \%$ & $2 \%$ & $2 \%$ \\
\hline
\end{tabular}

Source: Primary Data Analysis (2020)

meat, and $2 \%$ had difficulty buying chicken meat during the COVID-19 pandemic.

During the COVID-19 pandemic, consumers preferring to buy chicken in traditional markets and modern markets decreased. Purchases of broiler chicken meat in vegetable stalls increased, while purchases of free-range chicken meat in vegetable stalls decreased. There were other places to buy chicken 
Table 4. The Location of Purchasing Chicken Meat in Sleman

\begin{tabular}{lcccc}
\hline \multirow{2}{*}{\begin{tabular}{l} 
Purchase Location \\
\cline { 2 - 5 }
\end{tabular}} & $\begin{array}{c}\text { Befoiler Consumers } \\
\text { COVID-19 } \\
\text { Pandemic (\%) }\end{array}$ & $\begin{array}{c}\text { During } \\
\text { COVID-19 } \\
\text { Pandemic (\%) }\end{array}$ & $\begin{array}{c}\text { Free-range Chicken Consumers } \\
\text { COVID-19 } \\
\text { Pandemic (\%) }\end{array}$ & $\begin{array}{c}\text { During } \\
\text { COVID-19 } \\
\text { Pandemic (\%) }\end{array}$ \\
\hline Traditional market & 46.67 & 41.67 & 50.00 & 30.00 \\
Modern market & 8.33 & 3.33 & 7.50 & 2.50 \\
Vegetable stall & 21.67 & 23.33 & 22.50 & 15.00 \\
Online & 3.33 & 13.33 & 7.50 & 32.50 \\
Chicken slaughterhouse & 10.00 & 6.67 & 7.50 & 10.00 \\
Mobile vegetable treader & 3.33 & 3.33 & 0.00 & 2.50 \\
Chicken meat stall & 6.67 & 6.67 & 5.00 & 5.00 \\
Farmers & 0.00 & 1.67 & 0.00 & 2.50 \\
\hline Total & 100.00 & 100.00 & 100.00 & 100.00 \\
\hline
\end{tabular}

Source: Primary Data Analysis (2020)

meat options that were less crowded.

During the COVID-19 pandemic, many consumers bought chicken online, through friends, and directly from farmers. Consumer went hopping online as well via Facebook or Whatsapp, which was then delivered to home. The reason consumers changed their shopping place was to reduce their outdoor activities and avoid large crowds to prevent COVID-19 transmission (Table 4.).

The COVID-19 pandemic did not prevent consumers buying chicken because it was their source of food. It is consistent with research conducted in Yogyakarta and Jabodetabek that the consumers continue to purchase chicken meat when avian influenza occurred in Indonesia. The difference is that the place to buy chicken meat did not change during avian influenza period, but it changed during the COVID-19 pandemic (Muladno \& Thieme, 2009).

\section{Validity and Reliability Test}

The validity test was conducted by using the Pearson Product Moment method using the SPSS version 22 application. The validity test was carried out with data from 50 respondents with a significance level of $5 \%$ so that the $r$-table value obtained was 0.279 . The validity test results showed that the 52 question items used had an r-value greater than 0.279 so that all the question items in the research questionnaire were declared valid.

The reliability test was carried out with the Cronbach's Alpha correlation technique using the SPSS version 22 application. The research instrument was declared reliable if it had a Cronbach's Alpha value of more than 0.60 .

The reliability test results show that all question items had a Cronbach's Alpha value of 0.963 , higher than 0.60 so that the research questionnaire is 
reliable and the results of filling out the questionnaire can be trusted.

\section{Fishbein Multi-Attributes}

The criteria for the belief value (bi) and the evaluation of the importance of the attribute (ei) were used as follows:

a. $1.00 \leq$ bi $/$ ei $<1.80$ means very disbelief / very unimportant

b. $1.80 \leq$ bi / ei $<2.60$ means not believe / not important

c. $2.60 \leq$ bi $/$ ei $<3.40$ means less believe / less important

d. $3.40 \leq$ bi / ei $<4.20$ means believe / important

e. $4.20 \leq \mathrm{bi} / \mathrm{ei}<5.00$ means strongly believe / very important

The criteria of consumer attitude with the interval scale 67.2 are used as follows:
a. $14 \leq$ Ao $<81.2$ means not very good
b. $81.2 \leq$ Ao $<184.4$ means not good
c. $184.4 \leq \mathrm{Ao}<215.6$ means ordinary
d. $215.6 \leq$ Ao $<282.8$ means good
e. $282.8 \leq$ Ao $<350$ means very good

\section{Fishbein Multi-Attributes Analysis of Broilers Chicken Meat}

Consumer attitudes towards broiler chicken meat were based on the level of belief and importance of the broiler chicken meat attributes. The broiler chicken meat consumer belief level was divided into two, namely trust and absolute trust. Consumers believed that purchased broiler chicken meat had attributes of formaldehyde-free, bacteria-free, disease-free, good taste, sufficient nutritional content, fresh chicken meat, less fat, clean skin from feathers, reasonable price, good benefits, and halal. Consumers strongly believed that purchased broiler chicken meat has a fresh aroma and bright meat color (Table 5.).

At the level of importance of the broiler chicken meat attributes, consumers thought all of the attributes were very important. The broiler chicken meat attributes' importance to consumers were meat color, meat aroma, fresh chicken meat, formaldehyde-free, halal, reasonable price, good benefits, clean skin from feathers, good taste, sufficient nutritional content, diseasefree, low fat, bacteria-free. The number of consumer attitudes obtained was 234.79, which was included in good criteria, meaning that consumers showed a good attitude towards broiler chicken meat by looking at each of its attributes so that consumers decided to buy broiler chicken meat (Table 5.).

The three main attributes of broiler meat for consumer preferences were chicken meat aroma, chicken meat freshness, and chicken meat color. The order of importance is following the results of research (Pratama et al., 2015) 
Table 5. The Result of Fishbein Multi-Attributes Analysis on Broilers Chicken Meat

\begin{tabular}{lccc}
\hline Broilers Chicken Meat Attributes & bi & ei & Ao \\
\hline Fresh meat aroma & 4.23 & 4.64 & 19.63 \\
Fresh chicken meat & 4.19 & 4.68 & 19.61 \\
Bright meat color & 4.22 & 4.62 & 19.50 \\
Formaldehyde-free & 4.06 & 4.66 & 18.92 \\
Halal & 4.01 & 4.68 & 18.77 \\
Appropriate price & 4.10 & 4.48 & 18.37 \\
Good benefits & 3.99 & 4.59 & 18.31 \\
Clean skin from feathers & 3.98 & 4.53 & 18.03 \\
Good taste & 4.01 & 4.40 & 17.64 \\
Sufficient nutritional content & 3.92 & 4.47 & 17.52 \\
Disease-free & 3.62 & 4.61 & 16.69 \\
Low fat & 3.78 & 4.32 & 16.33 \\
Bacteria-free & 3.47 & 4.46 & 15.48 \\
\hline \multicolumn{2}{c}{ Consumer Attitude (Ao) } & & 234.79 \\
\hline
\end{tabular}

Source: Primary Data Analysis (2020)

which shows that the order of importance of broiler meat is a carcass, carcass color, the smell of meat, freshness of meat, cleanliness of skin, bone condition, and carcass size of broilers. Research conducted (Simarmata et al., 2019) also shows that the attributes of chicken meat color and aroma of chicken are the most important. Consumers liked broiler chicken since it had a shiny yellowish-red meat color and smells fresh. Research conducted by (Mayulu et al., 2019) shows that the freshness of the meat and the chicken's color rank first and second as attributes were taken into account by consumers in buying broiler meat. Consumers chose chicken meat with golden yellow meat color, clean skin from feathers, medium meat size, no bruises, fresh meat, and chicken breast pieces.
Fishbein Multi-Attributes Analysis of Free-range Chicken Meat

The value of consumer attitudes (Ao) for each attribute in free-range chicken meat was greater than the broilers, accompanied by differences in attributes' level of importance. In purchasing free-range chicken meat, the consumer belief level in the free-range chicken meat attributes was higher than that of broiler chicken meat. The number of free-range chicken meat attributes indicates that consumers' trust in freerange chicken was bigger than broiler chicken meat. Consumers strongly believed that the free-range chicken meat purchased had the attributes of formaldehyde-free, good taste, sufficient nutritional content, fresh chicken meat, fresh meat aroma, low fat, good benefits, and halal. Consumers believed that free- 
range chicken meat had the attributes of bacteria-free, disease-free, dark meat color, clean skin from feathers, and reasonable price.

At the level of importance, the free-range chicken meat attributes were the same as those of broilers. Consumers argued that all the free-range chicken meat attributes are essential. Unlike broiler chicken, the three main attributes of free-range chicken based on consumer preferences were chicken meat freshness, chicken meat aroma, and halal.

The halal attribute in chicken meat was the attribute that could not be seen and felt but was more on each consumer's belief. Not all chicken traders put a halal label on the chicken they sold. The majority of consumers buying chicken meat based on trusting the seller that the chicken purchased was halal. Consumers already knew about the production process of broilers and free-range chickens, and believed more ont the production process of free-range chicken which was considered halal so that the halal attribute became the three main attributes of free-range chicken meat preferences.

Consumer attitude towards freerange chicken with a value of 249.24 was considered good, and the value was higher than that of broilers. It shows that consumers would tend to choose freerange chicken meat than broilers, which might be caused by consumers having a higher belief and importance in the freerange chicken meat attributes (Table 6.). These results are consistent with the research conducted (Kyarisiima et al., 2011 ) revealing that $80 \%$ of consumers

Table 6. The Result of Fishbein Multi-Attributes Analysis on Free-range Chicken Meat

\begin{tabular}{lccc}
\hline Free-range Chicken Meat Attributes & bi & ei & Ao \\
\hline Fresh chicken meat & 4.29 & 4.72 & 20.25 \\
Fresh meat aroma & 4.32 & 4.65 & 20.10 \\
Halal & 4.26 & 4.70 & 20.00 \\
Sufficient nutritional content & 4.29 & 4.63 & 19.86 \\
Formaldehyde-free & 4.21 & 4.71 & 19.83 \\
Good benefits & 4.30 & 4.61 & 19.82 \\
Good taste & 4.32 & 4.56 & 19.70 \\
Low fat & 4.23 & 4.51 & 19.10 \\
Appropriate price & 4.16 & 4.55 & 18.93 \\
Clean skin from feathers & 4.12 & 4.57 & 18.83 \\
Disease-free & 3.79 & 4.72 & 17.88 \\
Dark meat color & 3.99 & 4.40 & 17.56 \\
Bacteria-free & 3.78 & 4.60 & 17.39 \\
\hline \multicolumn{2}{c}{ Consumer Attitude (Ao) } & & 249.24 \\
\hline
\end{tabular}

Source: Primary Data Analysis (2020) 
prefered local chicken over broilers. Most consumers were suspicious on the broiler chicken's safety and accepted local chicken as the tastiest and safest meat than the other chicken. Consumer preference for local chicken meat opened a potential opportunity for local Ugandan chicken businesses in the Kampala meat market.

\section{CONCLUSION AND SUGGESTION}

This study concludes that consumers continued to buy chicken meat with changes in the number of purchases according to their circumstances during the COVID-19 pandemic. Consumers changed chicken meat purchase locations from markets to direct sellers or online in order to reduce the intensity of meeting people during the COVID-19 pandemic. The three main attributes of consumer preferences for broilers were chicken meat aroma, chicken meat freshness, and chicken meat color, while the three main attributes of free-range chicken were chicken meat freshness, chicken meat aroma, and halal status.

The suggestion that can be given through this research is that chicken meat traders must pay attention to the three main attributes of chicken meat when selling chicken directly to buyers or via Whatsapp or online during the COVID-19 pandemic. Buyers will feel safe and believe in the chicken meat even though they do not choose directly because the traders have paid attention to the three main attributes of the chicken meat, also buyers will believe on traders and continue to buy chicken meat on them.

\section{REFERENCES}

Abdul Hadi, A. H. I., Shamsudin, M. N., Radam, A., \& Selamat, J. (2013). Consumer Preference for Food Attributes in Malaysia: Case Studies on Broiler and Beef. Journal of International Food and Agribusiness Marketing, 25(SUPPL1), 137-153. https://doi.org/10.1080/089744 38.2013 .805453

Badan Pusat Statistik. (2019). Tabel Dinamis Produksi Daging Ayam Ras Pedaging dan Ayam Buras menurut Provinsi. Badan Pusat Statistik. www.bps.go.id

Choe, J. H., Nam, K., Jung, S., Kim, B., Yun, H., \& Jo, C. (2010). Differences in the quality characteristics between commercial Korean native chickens and broilers. Korean Journal for Food Science of Animal Resources, 30(1), 13-19. https://doi. org/10.5851/kosfa.2010.30.1.13

Dinas Pertanian Yogyakarta. (2020). Populasi Ternak Unggas 
Kabupaten/Kota di D.I.Yogyakarta. h t tp: / / distan.jog ja prov. go.id/wp-content/download/ peternakan/2009-2013/tabel_4_ populasi_ternak_unggas_kab.kota_ di_diy.pdf

Jayaraman, K., Munira, H., Chowdhury, D., \& Iranmanesh, M. (2013). The Preference and Consumption of Chicken Lovers with Race As A Moderator - An Empirical Study in Malaysia. International Food Research Journal, 20(1), 165-174.

Kwadzo, G., Dadzie, F., Osei-Asare, Y., \& Kuwornu, J. K. M. (2013). Consumer Preference for Broiler Meat in Ghana: A Conjoint Analysis Approach. International Journal of Marketing Studies, 5(2). https:// doi.org/10.5539/ijms.v5n2p66

Kyarisiima, C. C., Naggujja, F. A., Magala, H., Kwizera, H., Kugonza, D. R., \& Bonabana-Wabbi, J. (2011). Perceived Tastes and Preferences of Chicken Meat in Uganda. Livestock Research for Rural Development, 23(11).

Mayulu, H., Rahman, A., \& Yusuf, R. (2019). Consumer's Preference of Broiler Meat Attributes in Traditional Markets. Hasanuddin
Journal of Animal Science, 1(2), 28-36.

Merlino, V. M., Borra, D., Verduna, T., \& Massaglia, S. (2017). Household Behavior with Respect to Meat Consumption: Differences between Households with and Without Children. Veterinary Sciences, 4(4). https://doi.org/10.3390/ vetsci 4040053

Mufeeth, M. M., \& Thariq, M. G. M. (2019). Evaluation of Consumer Preference for Value Addition to Native Chicken Meat and Egg. SEUSL Journal of Marketing, 4(1), 2019.

Muladno, M., \& Thieme, O. (2009). Consumer Preferences for Poultry Products in Indonesia. GCP/ RAS/228/GER Working Paper No. 12,12 .

Pouta, E., Heikkilä, J., Forsman-Hugg, S., Isoniemi, M., \& Mäkelä, J. (2010). Consumer Choice of Broiler Meat: The Effects of Country of Origin and Production Methods. Food Quality and Preference, 21(5), 539546. https://doi.org/10.1016/j. foodqual.2010.02.004

Prasetijo, R., \& Ihalauw, J. J. O. I. (2005). Perilaku Konsumen. Andi, Yogyakarta. 
Pratama, I. G. W., Sukananta, I. W., \& Parimartha, I. K. W. (2015). Analisis Preferensi Konsumen dalam Membeli Daging Ayam Broiler di Pasar Tradisional Kota Denpasar. Journal of Tropical Animal Science, $V, 549-560$.

Purwoto, A. (2007). Panduan Laboratorium Statistik Inferensial. Grasindo, Jakarta. https://books. google.co.id/books/about/
Panduan_Lab_Statistik_Inferensial. html?id=jW2fTDlu0z0C\&redir_ esc $=\mathrm{y}$

Simarmata, L., Osak, R. E. M. ., Endoh, E. K. ., \& Oroh, F. N. . (2019). Analisis Preferensi Konsumen Dalam Membeli Daging Broiler Di Pasar Tradisional Kota Manado (Studi Kasus "Pasar Pinasungkulan Karombasan"). Zootec, 39(2), 194202. 